\title{
Public management of the institutional environment of food security in Ukraine
}

Gacim Salah, PhD, Research professor of Polydisciplinary Faculty of Smara Ibn, Zohr University, Agadir, Morocco, Laboratory of Studies and Applied Researches in Economic Sciences (LERASE), salah.gacim@edu.uiz.ac.ma,oRCID 0000-0002-2547-1752

Yurii Lupenko, doctor of economic sciences, professor, academician of NAAS, director of National Scientific Centre "Institute of Agrarian Economics", vice-president of the National Academy of Agrarian Sciences of Ukraine, pd@iae.org.ua, ORCID iD https://orcid.org/0000-0001-6846-0300

Olena Nikoliuk, Doctor of Economic Sciences, Associate Professor of the Department of Management and Logistics, Odessa National Academy of Food Technologies, ORCIDID:0000-0002-1665-0361, alenavn11@gmail.com

Inna Yu Gryshova , Doctor of Economic Sciences, Professor Department of Public Administration and Innovation Management, National University of Life and Environmental Sciences of Ukraine 6020180146@jsnu.edu.cu,ORCID0000-0001-6276-7619

Aliaksei Zhurauliou , Doctor of Economic Sciences Professor at the Department of Urban Economy, Kyiv National University of Construction and Architecture, zhuravlov.ov@knuba.edu.ua, ORCID 0000-0002-32869224

Oleksii Diachenko, Doctor of Science in Public Administration, Professor Odessa State Agrarian University, Ukraine, ORCID ID: 0000-0001-9670-2266

\begin{abstract}
The aim of the article is to identify trends in the trajectory of public administration of food security development in Ukraine. The global pandemic has posed challenges for all national economies, but the state of food security and its adjustment through appropriate public governance are of particular importance. It is proved that the current state of the institutional environment on the economic system is dynamic. Proposed theoretical models, which include various institutional factors. The evaluation of the models allowed us to conclude that the overwhelming statistical significance of institutional factors on the success of economic transformations. The article found that there is no statistically significant relationship between food supply and political stability in Ukraine, but using FAO's online food security forecasting tools to 2030 threatens to increase the number of malnourished people to 5.5 million. In our opinion, this is a possible consequence of the deteriorating state of political stability in the country in the long run and which indicates the dominance of extractive informal institutions in the trajectory of Ukraine's economic development.
\end{abstract}

Keywords: public management, covid pandemic, food supply, political stability, shadow economy, institutional environment, FAO, forecasting, undernourishment, environmental safety.

$\begin{array}{lll}\text { Received: 08.12.2020 } & \text { Accepted: 14.01.2021 } & \text { Published: 07.02.2021 }\end{array}$

\section{Introduction}

In the conditions of Covid pandemic, the problem of food safety arises. According to FAO estimates, the pandemic will see more than a quarter of a billion people suffering acute hunger by the end of the year, according to new figures from the World Food Program (WFP). In these difficult conditions, Ukraine has not only economic prerequisites for increasing food production, but also to reach a new level of public food security management, improve the conditions of agricultural production, launch the land market. (Gryshova, I.; Kyzym, M.; Hubarieva, I.; Khaustova, V.; Livinskyi, A.; Koroshenko, M, 2020); (Dragan Ivan.O., Kovalova Olena, Gryshchenko Iryna, Ridei Nataliia, Livinskyi A. I, 2020)

In post-socialist countries the transformation of the institutional environment from extractive to inclusive institutions becomes an immanent process that affects the nature of economic development. Such countries include Ukraine, where the dominance of extractive and informal institutions has determined the trajectory of economic development.

Deaton and Lipka (2015) analyzed the relationship between political stability and food security and determined the strong correlation. In the report of FHI 360 (2020) the intricate connections between agriculture, food security, and governance suggest that attempts to reduce chronic hunger must integrate all three elements. In particular, certain principles of governance - participation, accountability, 
transparency, effectiveness, and the rule of law - should be integral parts of programs for agriculture and food security. (Popov, A., Kniaz, O., Koshkalda, I., Trehub, 0, 2019).

Thus, the purpose of this research is to analyze the state and dynamics of food security in Ukraine, and the impact of the institutional factors on food security.( Kyzym, M., Khaustova, V., Reshetnyak, O., Danko, N., 2020)

\section{Materials and methods of research}

The statistics of the study includes: data from the UN Food and Agricultural Organization (hereinafter FAO), data from the State Statistics Service of Ukraine on the state of food security; analytical data from national research centers.

Taking into account the goal in the study we used methods of analysis, regression modelling and comparisons, groupings. (Bilynska M, Baltsii Yurii, Boyarskyy Oleksandr, Bykova Tetiana Valerijivna, Gryshova Rymma, 2020)

\section{Results and discussions}

World food prices continued to rise for the seventh straight month in December, with the highest increases in dairy and vegetable oil prices, according to data released today by the Food and Agriculture Organization of the United Nations.( Gryshchenko I. M., 2016).

Ukraine is a country with traditionally strong production of agricultural products. This is due to the historical paradigm, climatic conditions, geographical location and so on. Exports of agricultural products are key to the economy, one of the most important sources of filling the state budget, as well as the inflow of currency. That is why the export of agricultural products, along with the export of industrial goods and services, is so important for the economic development of Ukraine. (Koshkalda, I., Kniaz, O., Ryasnyanska, A., Velieva, V., 2020)

In table. 1 there is the dynamics of value added of agricultural production in Ukraine (as a percentage), which gives agricultural production.

Table 1. Value added of agricultural production in Ukraine, \%

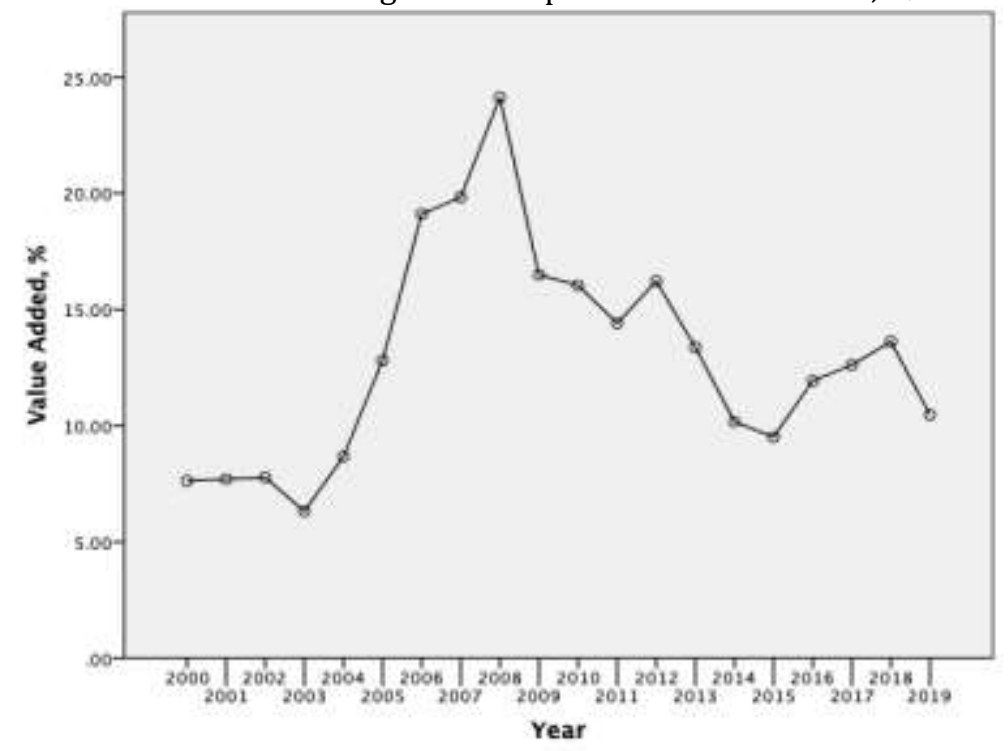

The rapid growth of agricultural production in Ukraine began in 2003. This is due to the favorable external situation in world markets, as well as the beginning of real democratic transformations in the country after the Orange Revolution. Value added in agricultural production in Ukraine peaked in 2008 and indicated that world markets were severely overheated in the run-up to the global economic crisis. The largest shares of agricultural exports were grain crops - $38.4 \%$ of the volume of agricultural exports, oil $-23.3 \%$ and oilseeds $-10.2 \%$. The growth of exports last year was provided mainly by corn, wheat, rapeseed, poultry meat and offal, oils, tobacco and tobacco products, eggs and confectionery. This is what currently forms the basis of agricultural production in Ukraine.

At the same time the importance of political stability in a country for food security is hard to overestimate. Below we have a dynamic of political stability data based on FAO statistics. 
Table 2. The dynamics of the political stability in Ukraine

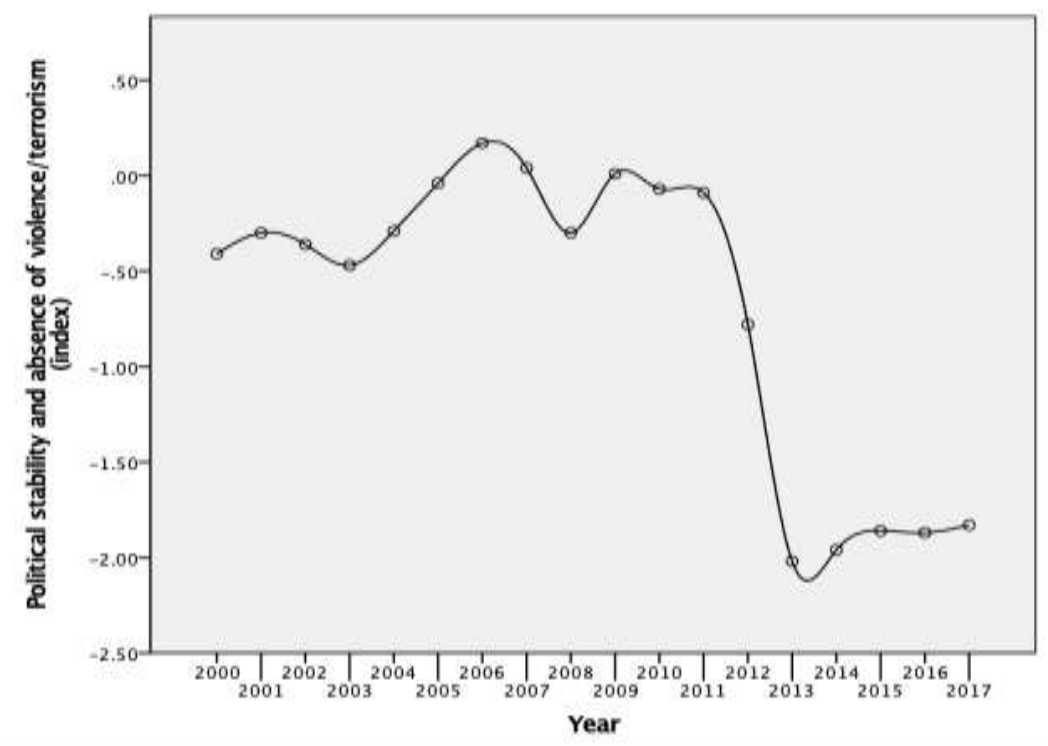

The increase of the political stability started with late Presidency of Leonid Kuchma and ended by the time of The Orange Revolution. Then followed several years of Yushchenko Presidency when political stability was due to improve again, but starting late 2013 a sharp drop happened.

At the same time there's no obvious correlation between declining political stability and food production. We analyzed the dynamics of food production variability (in International dollars) in Ukraine from 2001 (table 3).

Table 3. Average value of food production (left). Per capita food production variability (I\$ per person constant) ( right).
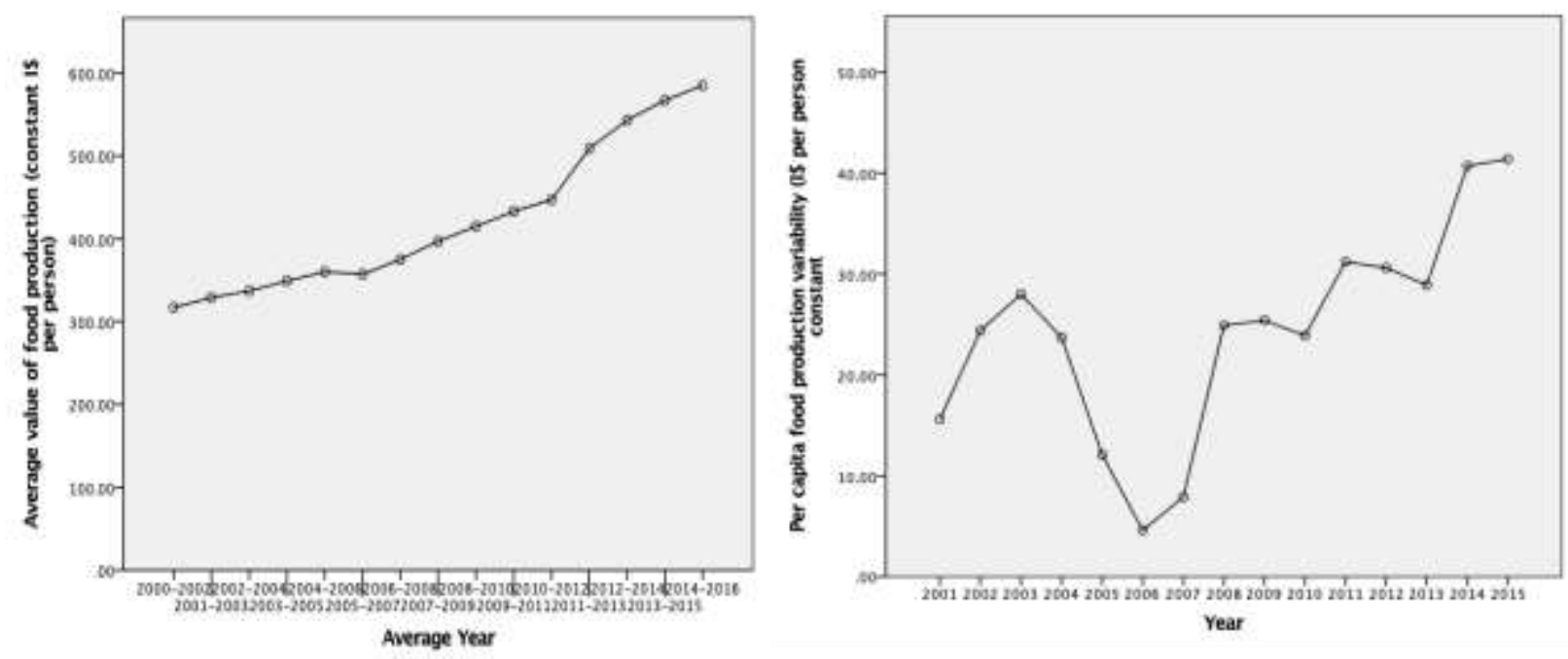

A significant part of food production in Ukraine is accounted for by small and medium-sized enterprises, which traditionally do not cooperate with each other to ensure stable level of quality and volume of supply required to operate in the global market, so the dominant role is played by large companies. The high level of concentration in the global market for food retail, food services and food production means that the Ukrainian sector must focus on selling its products through the main distribution channels if it is to have a significant impact on the market. It should also be noted that large distributors require compliance with certain conditions: the formation of large batches of products, flexible conditions and prices, as well as short deadlines for delivery orders. At the same time, food producers, for their part, seek 
to establish a stable uninterrupted supply of the necessary semi-finished products and ingredients on the basis of 10-year investment plans.

The growing level of hygiene requirements and food safety standards means that food and processing industry producers in all parts of the chain value creation products must have appropriate quality assurance systems so that their products are acceptable to export markets. The costs of quality control should be taken into account in the business model of production. Growing attention to environmental aspects by consumers means that a large number of retail chains want to buy products nearby and deliver them by auto transport. In this context, Ukraine can offer the EU (the largest food retail market in the world) a number of products that meet these requirements. However, manufacturers need to monitor CO2 emissions, meet the latest product packaging requirements and use alternative packaging options.

The gross volume of agricultural production in Ukraine is quite significant and is $18-19 \%$ of GDP. The agricultural sector employs almost 3 million people, which is $18 \%$ of the working population of Ukraine. Agricultural production increased by $6.8 \%$ in recent years and reached UAH 10 billion in 2019 (74\% cultivation of agricultural crops, $26 \%$ - animal).

In order to estimate the relation between food supply and political stability in Ukraine we use OLS method and get the following results.

$\hat{\mathrm{y}}=\mathrm{bX}+\mathrm{a}$

where $y$ - food production in Ukraine,

$\mathrm{X}$ - dynamics of political stability in Ukraine.

The Regression statistics is presented below:

Sum of $X=363.3$

Sum of $Y=-8.32$

Mean $X=24.22$

Mean $Y=-0.5547$

Sum of squares $(\mathrm{SSX})=1567.104$

Sum of products (SP) $=-82.0916$

Regression Equation $=\hat{y}=\mathrm{bX}+\mathrm{a}$

$\mathrm{b}=\mathrm{SP} / \mathrm{SSX}=-82.09 / 1567.1=-0.05238$

$\mathrm{a}=\mathrm{MY}-\mathrm{bMX}=-0.55-(-0.05 * 24.22)=0.71408$

$\hat{y}=-0.05238 X+0.71408$

We investigated this relationship and came up with the insight that declining political stability in Ukraine doesn't have statistically significant impact on the food production in Ukraine. This result doesn't match the insights of Deaton and Lipka (2015) and here's our explanation of this phenomena. There's a vast share of shadow economy in Ukraine that on one side help SME to produce food under minimum or none supervision of the State, but on the other side there's a lack of foreign investment into the agricultural sector of the Ukrainian economy that could have improved the technological level of food production.(Hryshchenko Iryna, Lavshchenko Svetlana, 2020) Here's another evidence of the paradox of no correlation between political stability and food security (table 4).

Table 4. Relationship between food supply and GDP per capita

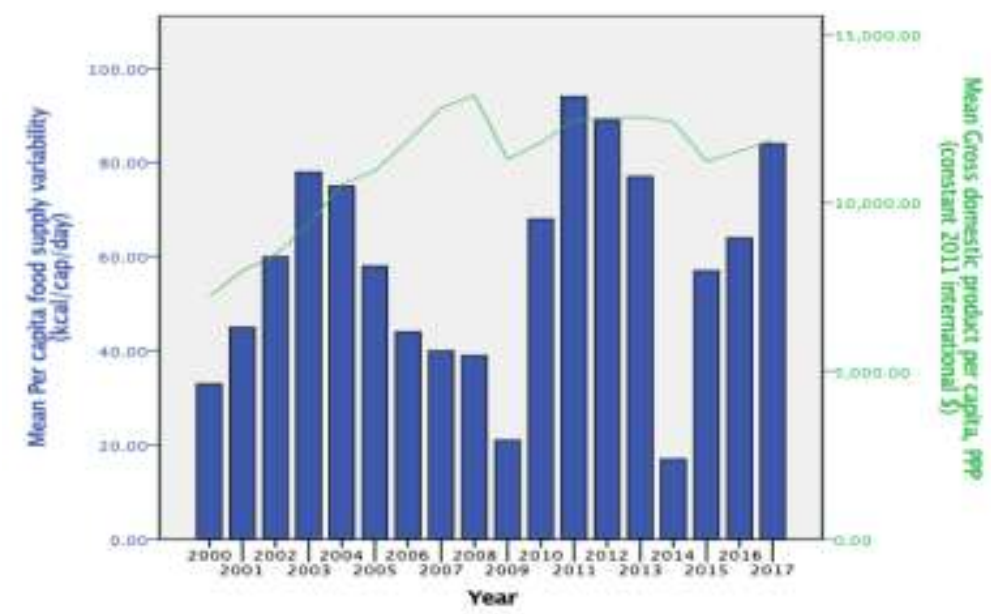

Despite the growth of national income since 2000, we can't see a significant correlation between GDP per 
capita and food supply variability that points out to the shadow economy factor and high demand for the new public management that could help laundry the shadow sector. (Semenyshyn, Mykola 0.; Hryshchenko, Iryna M.; Alekseieva, Kateryna A.; Oliinyk, Volodymyr V.; Buha, Ha nna S. , 2020)

With this statistical data and modelling it's quite difficult to make a forecast the food security in Ukraine till 2030 and taking into account the importance of food security in post-Covid world we used the special FAO tool - Prevalence of Undernourishment (PoU) that is publicly available on the official site of FAO. Tool allows you to reproduce and plot the country PoU series estimated by FAO up to 2030 and simulate alternative scenarios for projections until 2030. The simulation results are presented in Table 5. You can read more about the calculation methodology on the FAO website [http://www.fao.org/publications/sofi]

Table 5. Forecasting of possible undernourishment in Ukraine till 2030

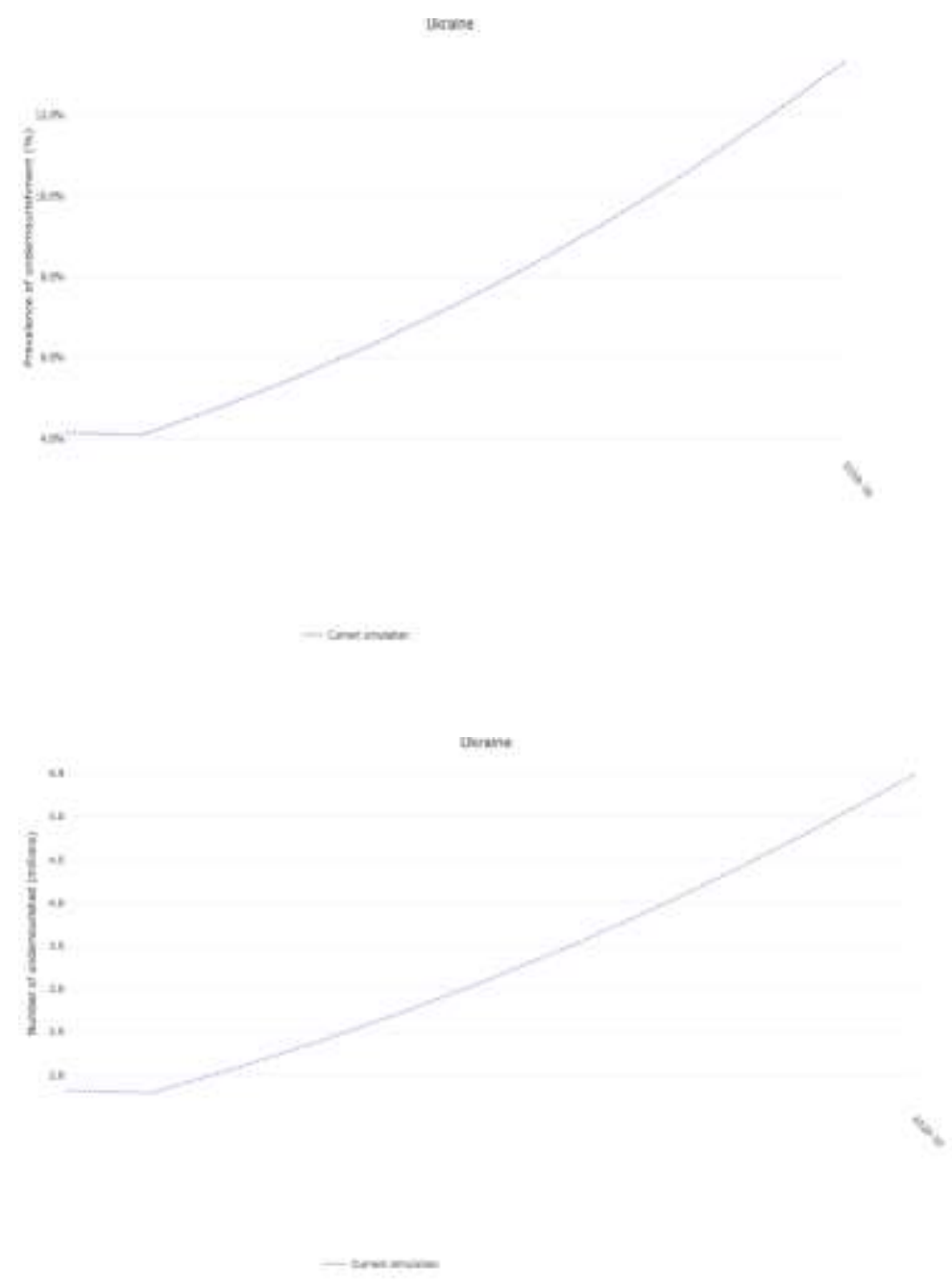

Given the current situation with the provision / consumption of food energy and access to food, the forecast indicates a threat to Ukraine in the period up to 2030, namely an increase in the number of people who may experience food shortages to 5.5 million people (or almost $15 \%$ of the population). (Vinogradova, E., Nikoliuk, O., Galimova, A, 2020); (Gryshova I.Yu Wadim Strielkowski(2018)

Although it is estimated that the number of malnourished people is declining in the world, there are threats that under bad governance the results can decline and at this rate there's not enough job done to reach international hunger reduction goals. This can be achieved through measures to improve access to food through safety networks and similar measures. Such measures are also in the long-term promise to positively impact accessibility food by increasing local demand, which will stimulate food production. To such programs include, in particular, monetary transfers and cash distribution programs, funds and vouchers. The first results of such programs indicate that they can lead not only to consumption growth, but also an increase in investment in agricultural assets, including rural machinery and livestock, as well 
as the growth of its own food production. Available facts say that such programs can have significant the multiplier effect due to the link between trade and production. In the longer term, they can

provide positive feedback when demand created through social safety nets, stimulates food production in small farms, thereby helping and consumers and producers from the poor population. These programs are two-fold approach to hunger reduction in which by stimulating demand for food, in its turn, incentives are created to build production and increasing opportunities for creating income in farms. To ensure their long-term viability plan efforts to increase demand require be supported by effective measures to improve offers. This is especially important in cases where programs to reduce hunger are calculated the large population of rural areas where there's a lack of sufficient physical and organizational infrastructure. Enhancement agricultural productivity leads to growth income and creates income generation opportunities for disadvantaged population, offering a proven a way out of the dead end of poverty in many rural areas. (Gryshova, I.; Demchuk, N.; Koshkalda, I.; Stebliuk, N.; Volosova, N., 2019);( Gryshova, I.; Shabatura, T.; Girdzijauskas, S.; Streimikiene, D.; Ciegis, R.; Griesiene, I., 2019)

We also considered the dynamics of CO2 emissions in Ukraine in the period from 1992 to 2017.

Table 6. Dynamics of CO2 emission in Ukraine (1992-2017)

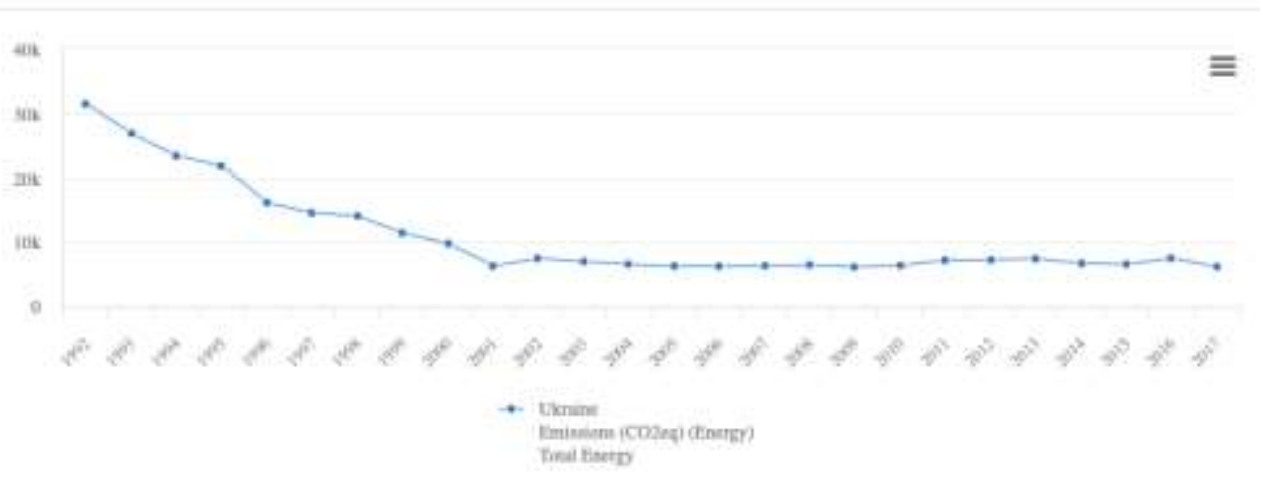

\section{Conclusions}

Summarizing the comparisons can be made the following conclusions.

1. Ukraine is currently in the process of transforming its economic system, which has objectively led to a decrease in the efficiency of its economic potential. The agro-industrial complex as the main producer of agricultural raw materials and food suffered particularly large losses. The sharp decline in effective demand of a large part of the population has led to a reduction in food consumption, unbalanced diet, which negatively affects the health and development of the nation.

2. Over the past three years, international investors in Ukraine have begun to increase the share of the agro-industrial complex in their investment plans. Over the past few years

the share of industry, wholesale trade and construction in foreign direct investment decreased significantly. However, investment in agriculture remains stable. In general, the share of agriculture in the portfolio of international investors has increased due to lower investment in other sectors. This trend is explained export orientation of agricultural companies, which represent mainly such areas as wheat cultivation, oil and poultry production.

3. The availability of basic foodstuffs and their physical availability is ensured by the domestic agroindustrial complex, the level and pace of expanded reproduction of which is the basis of national food security and the realization of its export potential. Economic affordability of food is characterized by the level of economic development, which determines the amount of income that allows the population to buy the necessary food at prices set in the food market.

4. The regression modelling showed the absence of statistically significant relationship between food production and political stability.

5. With the help of FAO online tool we conducted the forecasting. Given the current situation with the provision / consumption of food energy and access to food, the forecast indicates a threat to Ukraine in the period up to 2030, namely an increase in the number of people who may experience food shortages to 5.5 million people (or almost $15 \%$ of the population).

\section{References}

1. B. James Deaton and Bethany Lipka. Political Instability and Food Security. Journal of Food Security. 2015; 3(1):29-33. doi: 10.12691/JFS-3-1-5 
2. ANNUAL REPORT 2018 https://www.fhi360.org/annual-report-2018

3. Zhurauliou A. Internetization and Global Institutionalization of Economic Systems. Statistics of Ukraine, 2017. - 4 (79) - p. 39-46.

4. Bilynska M, Baltsii Yurii, Boyarskyy Oleksandr, Bykova Tetiana Valerijivna, Gryshova Rymma. Modern criteria for the effectiveness of the mayor as a leader in the local government system. Solid State Technology Vol. 63 No. 5 (2020) p. $5844-5867$

5. Kyzym, M., Khaustova, V., Reshetnyak, O., Danko, N. Significance of Developmental Science under Assimilation of the Digitalization of the Ukrainian Economy. International Journal of Advanced Science and Technology. 2020. Vol. 29(6s). P. 1037 - $1042 . \quad$ URL: http://sersc.org/iournals/index.php/IJAST/article/view/9167

6. Dragan Ivan.O., Kovalova Olena, Gryshchenko Iryna, Ridei Nataliia, Livinskyi A. I. Assessment Of The Role Of The State As A Leader In The Demographic Development Of Ukraine. Solid State Technology Vol. 63 No. 6 (2020) p.6630-6639

7. Gryshova, I.; Kyzym, M.; Hubarieva, I.; Khaustova, V.; Livinskyi, A.; Koroshenko, M. Assessment of the EU and Ukraine Economic Security and Its Influence on Their Sustainable Economic Development. Sustainability 2020, 12, 7692.

8. Gryshova, I.; Kyzym, M.; Khaustova, V.; Korneev, V.; Kramarev, H. Assessment of the Industrial Structure and its Influence on Sustainable Economic Development and Quality of Life of the Population of Different World Countries. Sustainability 2020, 12, 2072.

9. Gryshova, I.; Shabatura, T.; Girdzijauskas, S.; Streimikiene, D.; Ciegis, R.; Griesiene, I. The Paradox of Value and Economic Bubbles: New Insights for Sustainable Economic Development. Sustainability 2019, 11, 6888.

10. Gryshova, I.; Demchuk, N.; Koshkalda, I.; Stebliuk, N.; Volosova, N. Strategic Imperatives of Managing the Sustainable Innovative Development of the Market of Educational Services in the Higher Education System. Sustainability 2019, 11, 7253.

11. Gryshova I.Yu Wadim Strielkowski(2018) Academic publishing and «predatory» journal. Nauka innov., 14 (1) C.5-12

12. Vinogradova, E., Nikoliuk, O., Galimova, A.Creation of the corporate information system based on knowledge economy. E3S Web of Conferences, 2020, 208, 03011

13. Gryshchenko I. M. The impact of personal needs on the formation of leadership. Scientific Bulletin of National Mining University (SciVerse Scopus), 2016, vol. 4, pp. 154-160. http://nbuv.gov.ua/UJRN/Nvngu_2016 4 222.

14. Semenyshyn, Mykola O.; Hryshchenko, Iryna M.; Alekseieva, Kateryna A.; Oliinyk, Volodymyr V.; Buha, Hanna S. Research of features of professional self-

actualization of civil servants through the determinants of information security. Revista San Gregorio. Num. 42 (2020). Special Edition-2020. P. 41-53.

15. Hryshchenko Iryna, Lavshchenko Svetlana. Impact of local market development on sustainable (stable) city development. First Conference on Sustainable Development: Industrial Future of Territories (IFT 2020). Section: Sustainable Cities and Society. E3S Web Conf. (24 November 2020). Vol. 208, 04009 (2020).

16. Muhammad Umar, Farrukh Muhammad, Khalid Bashir, Sarfraz Hassan, Sultan AliAdil, Marit E.Kragt Mapping the food security studies in India, Pakistan and Bangladesh: Review of research priorities and gaps. Global Food Security. Volume 26, September 2020, 100370.

17. 17 Lilian Korir, Marian Rizov, Eric Ruto Food security in Kenya: Insights from a household food demand model. Economic Modelling. Volume 92, November 2020, Pages 99-108.

18. Popov, A., Kniaz, O., Koshkalda, I., Trehub, O. Land fragmentation of agricultural enterprises in the context of administration of land.Economic Annals-XXI, 2019, 176(3-4), стр. 80-90

19. Koshkalda, I., Kniaz, O., Ryasnyanska, A., Velieva, V. Motivation Mechanism for Stimulating the Labor Potential. Research in World Economy, 2020, 11(4), стр. 53-61 